\title{
English CFL Learners' Acquisition of le in Chinese Pivotal and Serial-events Sentences: A Corpus-based Study
}

\author{
Mengmeng Tang \\ School of Foreign Languages, China University of Petroleum, China
}

Received January 6, 2019; Revised February 18, 2020; Accepted February 24, 2020

Copyright $\subseteq 2020$ by authors, all rights reserved. Authors agree that this article remains permanently open access under the terms of the Creative Commons Attribution License 4.0 International License

\begin{abstract}
Chinese and English have typological differences in marking the temporal categories of verbs in sentences with multiple verbs. The perfective morpheme "le"is conventionally used after V2 to mark the completion of the event-continuum represented by both V1 and V2 in Chinese pivotal or serial-events sentences. In reminiscent English sentences, V1 inflects with tense and takes the suffix "-ed". The current study aims to investigate if the contrast between English and Chinese influences Chinese English as foreign language (CFL) learners' acquisition of "le" in pivotal and serial-events sentences. Via an analysis in HSK dynamic written composition corpus, we found misuses about mis-positioned "le" and lexical collocations in pivotal and serial-events sentences. The results showed that English CFL learners were influenced by English past tense marker "-ed" in the production of "le" in pivotal and serial-events sentences. L2 proficiency was not an influential factor in misusages but played a role in the total usage of these structures, i.e., high-proficiency learners produced these sentences more frequently than low-proficiency learners. It suggests that English CFL learners may have used the tense cue in their L1 to compose Chinese sentences with multiple verbs, and with the development of L2 proficiency, they tended to use pivotal or serial-events sentences more frequently. This finding reveals the morpho-syntactic transfer from English L1 to Chinese L2, contributes to the theories in second language acquisition in general, and gives pedagogical implications on Chinese L2 teaching.
\end{abstract}

Keywords Pivotal Sentences, Serial-Verb Constructions, le, English CFL Learners

\section{Introduction}

English and Chinese are typologically distant languages, and have contrasts in morpho-syntactic features. English is a tense language, and verbs inflect in terms of tense. Chinese as a tenseless language has aspectual markers, such as the perfective morpheme "le", to mark the completion of events. "Le" functions similar with the English suffix “-ed” when there is only one verb because both of them indicate the temporal category of past. However, they differ in usages in some unique-to-Chinese sentences, such as pivotal sentences and serial-event sentences.

Pivotal sentences "contain a noun phrase that is simultaneously the subject of the second verb and the direct object of the first verb” [10, p.607]. E.g., tā pài yīgè rén jiēle wǒ (he arrange one person pick up PFV me) "he arranged one person to pick up me". "Le” is put after V2, and there is no such an English counterpart [1][11]. Serial-events sentences, in a broad sense, is a syntactic structure in which two or more verbs are juxtaposed to form a complex predicate to express a series of related events within a single clause (e.g., [2], [5], [6], [10], [16], [22]) E.g., tā tuō xié jìnle wū (he take off shoes enter PFV house) "he took off his shoes to enter the house". Similarly, "le" is also after V2, and it has no such English counterparts.

English does not have such constructions where the multiple verbs are regarded as a complex or compound predicate. The multiple verbs in a single clause must take the form of finite and nonfinite verbs. Therefore, for English CFL learners, pivotal sentences and serial-events sentences are unique-to-L2 structures even if they did share some similarities with English sentences with nonfinite verbs as object complement (e.g., he called her to come here) or purposive adverbial (e.g., he took off his shoes to enter the house) on the surface structure.

Given these typological differences, we predict that pivotal sentences and serial-events sentences pose learnability problems for English CFL learners. Previous 
studies noticed that in Chinese as L2 learners' acquisition of pivotal sentences and serial-events sentences, they had the problems of underusage and misusages (e.g., [21], [27]). The second-generation heritage language learners were also found to under-employ serial-events sentences in previous studies (e.g., [4], [14], [15]). However, these studies investigated L2 learners from different L1s and regarded misuses as a developmental problem. The question of whether the usage of past tense marker in reminiscent English sentences with finite and nonfinite distinctions has an influence on L2 learners' misuses remains unclear. With this research gap, the current study aims to analyze the misuses in English CSL learners' corpus and reveal if the cross-linguistic difference influences the L2 acquisition of Chinese pivotal and serial-events sentences. It can effectively supplement previous studies, and provide pedagogical implications in the teaching of unique-to-L2 grammars.

\section{Literature Review}

\subsection{Le in Chinese Pivotal and Serial-events Sentences}

A pivotal sentence is defined as: "of the two predicates in a sentence, the object of the first predicate (verb) is at the same time the subject of the second one" [11, p.485]. Two pieces of information arise from this definition: the two verbs are all regarded as predicates, and the frame of the structure is that a noun "pivot" connects V1 (verb one) and V2 (verb two), functioning both as the object of V1 and as the subject of V2. See example (1a).

(1a). Tā ràng wó chàng yī zhī gē.
He let I sing a song.
'He let me to sing a song.'

Whenever the sentence marks the completion of the series of events, perfective morpheme "le" is added to the V2 rather than V1. Xing [24] mentioned that most of the 180 verbs which can comprise pivotal sentences are not followed by aspectual morphemes and, when morphemes do occur, they always follow the pivot predicate. see example (1b).
(1b). Tā ràng wǒ chàng le yīzhī gē.
He let I sing PFV a song.
'He let me to sing PFV a song'.

In the current research, we define the serial-events sentences in a narrow sense, and only use the term to refer to the sentences in which all verbs share the same grammatical subject, have no connective markings, under the same grammatical category, i.e., tense, modality, aspect, and are in a fixed order [22]. The sub-events which are represented as a series of verbs appear to be separate but indeed are understood as being related to each other either as one consecutive event, the purpose, the alternation or the circumstance of another event [10]. See example (2a). (2a). Tā qù shūdiàn kàn shū.
He go bookstore read book.
'He went to the bookstore to read books.'

In a serial-event sentence, "if one wants to emphasize the completion of an action, one normally puts the aspectual particle le at the end of the sentence" [11, p. 481]. See example (2b).

(2b). Tā qù shūdiàn kàn le shū.

$\mathrm{He} \quad$ go bookstore read PFV book.

'He went to the bookstore to read PFV books.'

To sum up, "le" is usually after V2 in pivotal sentences and serial-events sentences and "-ed" in similar English sentences is after V1. Specifically speaking, in sentences with single verbs, "le" is similar with English "-ed"; however, in Chinese sentences with double verbs, such as pivotal sentences or serial-events sentences, the position of "le" is different from "-ed" in reminiscent English sentences.

\subsection{Previous Studies in English CSL Learners' Acquisition of Pivotal and Serial-events Sentences}

The difficulties associated with learning Chinese-specific sentences have been investigated by researchers (e.g., [21], [27]). In Zhou [27]'s study, it was found that, in the Foreign Students' Chinese Interlanguage Error Corpus [28] with 900,000 words, 1,321 sentences (including 1,173 correct usage and 148 misusages) were pivotal sentences while Chinese native speakers produced 2,171 pivotal sentences in the native Chinese speakers' corpus with similar word counts. This shows that Chinese as L2 learners underuse these sentences. The usage of pivotal sentences increases in accordance with school grade, which indicates the role of L2 proficiency here. The errors tended to be the omission of a pivot or pivot predicate, the redundancy of verbs, incorrect word order and non-target-like word collocation.

The underuse of serial-event sentences was also observed in previous studies [21]. L2 learners of Chinese used 1,651 serial-events sentences in the Foreign Students' Chinese Interlanguage Error Corpus [28] of 900,000 words, while the native Chinese speakers used 1,930 serial-event sentences with the same words count. It emerged that L2 learners overused the directional verbs, such as dào (arrive), qù (go), lái (come): among the 1651 serial-event sentences, 1,024 contained directional verbs (53.06\%). In contrast, native Chinese used 1,930 serial-event sentences, of which only 598 contained directional verbs (30.98\%). Learners' usage of serial-events sentences increased in line with their L2 proficiency. Their errors tended to be incorrect word order, redundant verbs, the omission of verbs and non-target-like collocations.

As stated above, the problems associated with the acquisition of pivotal and serial-event sentences noted in the previous studies stressed learners' underuse, and the 
misused forms included omission, redundancy, incorrect word order and non-target-like collocations. These researches provide us with general information about the difficulties and misuses in the L2 acquisition of pivotal and serial-event sentences, but the limitations are a lack of further discussion about the possible reasons for each type of error, and the neglect of the learners' L1 backgrounds. If and how the morphological finite and non-finite distinctions in the L1 influence the acquisition of Chinese compound predicates remains unclear. In further exploration, a comparison of the learners' interlanguage with the L1 and the L2 and an investigation of the usage of aspectual markers in these constructions is needed.

\subsection{Cross-Linguistic Influence in Second Language Acquisition}

Cross-linguistic difference between the L1 and the L2 is an important factor in second language acquisition. It was first proposed using the term "language transfer". "Transfer is the influence resulting from the similarities and differences between the target language and any other language that has been previously (and perhaps imperfectly) acquired” [17, p. 27]. By the 1980s, some researchers were choosing to use the term "cross-linguistic influence" (CLI) to replace "transfer", since the latter is mainly associated with behaviorism [8][18]. In this article, transfer and cross-linguistic influence will be used interchangeably as a neutral term to refer to the phenomenon in question.

Transfer analysis has been used in studies of cross-linguistic influences. The term "transfer analysis" has been developed from contrastive analysis and error analysis. "Contrastive analysis is the systematic comparison of two or more languages" [17, p. 165]. Error analysis refers to the comparison of the learner's interlanguage with the target language. Interlanguage is the linguistic system used by second language learners who are in the process of learning a target language [19][20]. Developing from comparative analysis and error analysis, transfer analysis denotes an investigation of the discrepancy between the target language and interlanguage with regard to the cross-linguistic influence [3].

Yip [25] notes that "prior knowledge and experience of one or more languages often conditions the way we make sense of any new experience of language learning. Well-developed, pre-established concepts and mental structures together with automatized cognitive processes often hinder restructuring and new development" (p. 14). Some researchers summarized the role of L1 transfer as a composing and compensating strategy which can help the learners to originate, develop, compose, and organize thoughts in the L2 production (e.g., [13]).

In contrast to the large body of evidence related to morpho-syntactic transfer from Chinese to English, the transfer of English structures to Chinese is more controversial. For example, in Yuan [26]'s study on Chinese reflexives, allowing both long-distance and the local antecedent (e.g., "Zhāngsāni rènwéi Lǐsìj xiāngxìn zijī/j." (Zhangsan think Lisi trust self)), English learners of Chinese with L1 only allowing a local antecedent (e.g., "Johni thinks Billj trusts himself $* \mathrm{i} / \mathrm{j}$.") have difficulties in acquiring long-distance antecedents. This difference is more pronounced when compared with Japanese learners of Chinese, whose L1 also allows both long-distance and local antecedents. This shows that the similarities between Chinese and Japanese may have facilitated the acquisition of long-distance antecedents. However, Yuan also argued that not everything can be explained by L1 interference because no differences in the acquisition of the free orientation of "zìjì" were found among Japanese and English learners of Chinese (e.g., "māmā gàosù nŭ'éri PROi bùyào jiāoguàn zìjī", (mother tell daughter not spoil self), the mother told her daughter not to spoil herself), which is probably a developmental problem due to misleading input.

In general, there exists considerable evidence that the L1 and L2 contrast will lead to the learning difficulties or L1 morpho-syntactic transfer in L2 acquisition. Similarities between the L1 and L2 may facilitate L2 acquisition. L2 proficiency also plays an important role; namely, the lower the L2 proficiency, the more L1 transfer occurs. However, there are also studies showing that L1 transfer during the initial stage is not universal. It is thus important to explore why, when, and how L1 transfer occurs, and what kind of property is transferred. The L1 transfer may concern the specific property and the specific features in the L1 and L2, and it can be a relative linguistic phenomenon.

\section{The Current Research}

\subsection{Research Questions}

With the inductive approach, the following three research questions were addressed:

RQ1: What are the problems in English CFL learners' acquisition of Chinese pivotal sentences and serial-events sentences?

RQ2: Does the temporal marker "-ed" in English influence English CSL learners' acquisition of "le" in Chinese?

RQ3: Does the L2 proficiency affect the pattern of usage?

\subsection{Method}

\subsubsection{HSK Dynamic Composition Corpus}

HSK dynamic composition corpus was set by Beijing Language and Culture University in 2006 with 4,240,000 characters. HSK dynamic composition corpus collected over 20,000 compositions by 11569 students in the HSK exams from 1992 to 2005 and it is the largest foreign students' interlanguage corpus in China. The errors are 
tagged with characters, words, sentences, passages, and punctual marks, and it is open to the public. The HSK dynamic composition corpus contains metadata about students' background such as age, country, and language skill level. In the corpus, 46 error types are labeled. The errors range from character level, word level, sentence level, to discourse level. \{\} is the wrong sentence tagger used to identify sentence misuses. Sentences were tagged with this tagger after the sentence, before the sentence punctuation, and pinyin were added to briefly indicate the type of misuse.

\subsubsection{Participants}

The current research chose all Chinese L2 learners from the UK who took HSK from 1996 to 2005 as participants, and probed into the misuses in pivotal and serial-events sentences. There were 108 participants, and one of them was not recorded with a score, so there were 107 valid written compositions. Table 1 displays the brief information of English CSL learners.

Table 1. Description of High- and Low-proficiency Learners in HSK Dynamic Composition Corpus

\begin{tabular}{|c|c|c|c|c|}
\hline Group & $\begin{array}{c}\text { Certificate } \\
\text { band }\end{array}$ & Number & $\begin{array}{c}\text { Composition } \\
\text { scores } \\
\text { Mean (SD) }\end{array}$ & $\begin{array}{c}\text { Total } \\
\text { words }\end{array}$ \\
\hline High-proficiency & A and B & 44 & $84.77(7.70)$ & 19697 \\
\hline Low-proficiency & C and No & 63 & $\begin{array}{c}73.10 \\
(11.34)\end{array}$ & 25135 \\
\hline
\end{tabular}

The participants were classified into two groups according to their band of the certificate in the HSK exams, in which certificate band $\mathrm{A}$ and $\mathrm{B}$ were ranked as the high-proficiency learners while certificate $\mathrm{C}$ and no certificate were ranked as the low-proficiency learners. This classification method was also used by $\mathrm{Wu}$ [23] in a classificatory study of Chinese as L2 learners' grammatical misuses.

\subsubsection{Procedure and Coding Method}

Table 2. Coding Method in Analyzing the HSK Dynamic Composition Corpus

\begin{tabular}{|c|c|}
\hline Criteria of coding & Coding method \\
\hline Sentence types & $1=$ pivotal sentence; 2 =serial-events sentence \\
\hline Misuse types & $\begin{array}{l}1=\text { mis-positioned aspectual morpheme; } \\
\text { 2=lexical collocation; } 3=\text { mixed sentences }\end{array}$ \\
\hline
\end{tabular}

Pivotal sentences and serial-events sentences were all extracted from 107 raw compositions written by English CSL learners from the UK. The misused types were divided to mis-positioned aspectual morphemes (wrong-place "le"), lexical collocations and mixed sentences (two or more sentences combing together).
Table 2 shows the coding method used in the current research.

\section{Results}

Before the data analysis, normalization was performed by dividing the total number of words by the number of participants in each group and the results multiplied by the misuse counts. The examples of learners' misuses are as follows:

(4a). *wǒ xiàn zài kào le zì jǐ de shílì dāng shàng yī wèi xiăo xuéjiāo shī.

I now rely PFV on my own ability become a primary school teacher. (Mispositioned aspectual morpheme)

This sentence should be "wǒ xiànzài kào zìjǐ de shílì dāng shàngle yī wèi xiăoxué jiàoshî" (I now rely on my own ability become PFV a primary school teacher.) "le" is after V2 to indicate the completion of the event.

(4b). *wǒ zuì zhōng tōu tōu păo qù le xué mó tuō chē.

I at last secretly go PFV learn motorbike. (Mispositioned aspectual morpheme)

The grammatical sentence is "wǒ zuì zhōng tōu tōu păo qù xué le mó tuō chē” (I at last secretly go learn PFV motorbike.) "le" should be after V2 if the event continuum has completed.

(5). *fù mǔ yī dìng yào gěi tā men yī gè liáng hăo de băng yàng

Parents should give them a good example. (lexical collocation misuses)

The grammatically correct sentence is "fùmǔ yīdìng yào gěi tāmen zuò yīgè liánghăo de băngyàng" (parents should gěi them be a good example). In single-verb sentences, "gěi" has the meaning of "give", and can be used as "give somebody something". However, in pivotal sentences, "gěi" is grammaticalized, so the V2 "be" cannot be omitted.

Table 3 shows that low proficiency learners had lexical collocation misuses in using pivotal sentences and serial-events sentences which respectively accounted for $80 \%$ and $100 \%$ of the total forms of misuses, and $20 \%$ of the misuse form in pivotal sentences was the wrong place aspectual morpheme "le". High proficiency learners had the misuse of mixed sentences in pivotal sentences, and mis-positioned aspectual morphemes in serial-events sentences. The amounts of the misuses among high- and low-proficiency learners were similar in the four types of sentences. 
Table 3. Description of the Use of Pivotal and Serial-events Sentences by English CFL Learners

\begin{tabular}{|c|c|c|c|}
\hline \multicolumn{2}{|c|}{ Sentence types } & Low-proficiency learners & High-proficiency learners \\
\hline \multirow{3}{*}{ Pivotal sentences } & Usage counts & 60.47 & 104.58 \\
\cline { 2 - 4 } & Misuse counts & 3.98 & 4.07 \\
\cline { 2 - 4 } & Misuse types & $\begin{array}{c}\text { Lexical collocations: } 80 \% \\
\text { Wrong-place "le": 20\% }\end{array}$ & Lexical cllocations:100\% \\
\hline \multirow{3}{*}{ Serial-events sentences } & Usage counts & 31.83 & 34.52 \\
\cline { 2 - 4 } & Misuse counts & 2.39 & 2.03 \\
\cline { 2 - 4 } & Misuse types & Lexical collocations: $100 \%$ & wrong-place "le": $100 \%$ \\
\hline
\end{tabular}

The small number of misuses indicate that English CFL learners have an inadequate usage of pivotal sentences and serial-events sentences. To further check if there were differences in the total usage between the two groups of learners, I calculated the frequency of the usages in the two groups (see Table 3). It was found that high-proficiency learners used pivotal (usage counts 104.58) and serial-events sentences (34.52) more frequently than that of low-proficiency learners (usage counts in pivotal sentences 60.47; in serial-events sentences 31.83).

In general, the misuse forms were mis-positioned aspectual morphemes, and improper lexicon allocations. In comparison with low-proficiency learners, high-proficiency learners had more frequent usage in most of the MVC sentences.

\section{Discussion}

\subsection{Cross-Linguistic Influence in the Production of Chinese Pivotal and Serial-events Sentences}

The mis-positioned aspectual morphemes found in pivotal and serial-events sentences among English CFL learners are argued to be attributed to the cross-linguistic influence from the L1 morpho-syntax.

In pivotal or serial-events sentences, aspectual morphemes (e.g., perfective marker "le") can be put after $\mathrm{V} 2$ to indicate the completeness of the event continuum, and thus both verbs are finite. This is different from the clear finite and non-finite distinction in English where "-ed" is put after V1, even though the word order, positions of verbs in these sentences are reminiscent between English and Chinese. English CSL learners may have regarded "le" (perfective aspectual particle) as the marker of past tense (-ed), and added "le" after the matrix verb to express the past time. Therefore, morpho-syntactic transfer occurred. The corpus-based analysis indicates that the English "-ed" did have some influence on English CFL learners' usage of "le" in pivotal and serial-events sentences, and the influence was reflected as morpho-syntactic transfer.

The current research provides new evidence on how English morpho-syntactic features influence the acquisition of Chinese structures. This is consistent with Jin [9]'s findings that English CFL learners are inclined to regard morpheme "le" as a tense marker and equate it to the English "-ed". The present findings imply that English learners not only equated the tense marker to the aspectual marker to express the temporal information, but also transferred the more abstract property "finiteness", which is marked by the tense marker in their L1, to Chinese.

\subsection{The Role of L2 Proficiency in the Production of Chinese MVCs}

L2 proficiency was not found to make a difference in the number of misuses, however, it played an important role in the frequency of using MVCs. That is, the higher the L2 proficiency, the more usage of pivotal and serial-events sentences. This can be interpreted as the natural developmental sequence in the L2 acquisition, that is, learners developed L2 competence gradually, from using simple sentences to complex sentences, and with the development of the L2 proficiency, learners would be more and more confident in using the relatively complex sentences. It may also be argued to be the intentional avoidance as a communication strategy. "It is obvious that communication strategy is the conscious employment of verbal mechanisms for communicating an idea when linguistic forms are not available to the learner for some reasons" [7, p. 1584]. Chinese as L2 learners were found to underuse pivotal sentences and serial-events sentences in comparison with Chinese natives in previous corpus-based studies [21][27], and the present study showed that English CSL learners of low-proficiency had even fewer usages of these sentences.

Other misused forms include the improper lexicon allocation. These were possibly attributed to the intralingual or developmental misuses, suggesting learners' unfamiliarity to the sentence patterns and lexicon allocation due to inadequate learning.

In sum, these results answered the research questions about what non-target like usages English CFL learners may have, and if they are a reflection of the cross-linguistic influence. Mis-positioned aspectual morphemes were argued to be the reflection of cross-linguistic influence from L1 reminiscent sentences. Misuses appeared randomly among CSL learners of 
different proficiencies, and no certain tendency was found with the increase of proficiency. However, L2 proficiency was found to play a role in the frequency of usage, that is, low proficiency learners tended to use fewer pivotal and serial-events sentences.

\subsection{Pedagogical Implications}

The research findings suggest that English CSL learners were not aware of the differences between the English tense marker "-ed" and the Chinese aspectual marker "le" in interpreting relations of multiple verbs. We thus propose an explicit grammatical illustration of aspectual features in pivotal and serial-events sentences, with a combination of the cutting-edge research, such as the finiteness theories. Teachers are also advised to design activities based on the L1 and L2 typological comparisons to raise English CFL learners' awareness of language characteristics.

\subsection{Limitations}

Even though HSK is one of the largest Chinese L2 learners' interlanguage corpora, there are some limitations in the corpus analysis. As a common disadvantage in all corpora studies, the recorded learners' written compositions cannot fully expose learners' acquisitional problems [12]. L2 learners may avoid the usage of certain types of sentences because of difficulties in comprehension, avoidance in learning strategies and etc.. Even though a handful of misuses were found in the corpus analysis, with the factors of a small-size sample pool, naturalistic productions and possibly varied learning method, it is immature to argue that English learners had a few difficulties in acquiring Chinese pivotal and serial-events sentences.

\section{Conclusions}

The current research aimed to explore the L1 influence on the acquisition of "le" in Chinese pivotal sentences and serial-event sentences. Via a corpus-based study, we found that the cross-linguistic influence was in the form of the mis-positioned aspectual markers in English CFL learners' production of pivotal and serial-events sentences. L2 proficiency was found to play a role in the frequency of usage, that is, low proficiency learners tended to use fewer pivotal and serial-events sentences. It suggests that English CFL learners may have used the tense cues in their L1 to interpret and compose Chinese structures with multiple verbs, and with the development of L2 proficiency, they tend to use these unique-to-Chinese structures more frequently. This finding contributes to the theories in second language acquisition in general, and gives pedagogical implications on Chinese as second language teaching.

\section{Acknowledgements}

This study was funded by the China Ministry of Education Humanities and Social Sciences Youth Fund Project (project number: 2015050023) and the Fundamental Research Funds for the Central Universities (project number: ZX20190052).

\section{REFERENCES}

[1] An, L., Liu, L. The contrastive study of the verbs in English SVOC structure and Chinese "jianyu" structure. Yanbian Daxue Xuebao (Shehui Kexue Ban) [Journal of Yanbian University (Social Science)], Vol.37, No.2, 90-93, 2004.

[2] Baker, M. C. Object sharing and projection in serial verb constructions. Linguistic Inquiry, Vol.20, 513-553, 1989.

[3] Chan, Y. Syntactic transfer evidence from the interlanguage of Hongkong Chinese ESL learners. The Modern Language Journal, Vol.88, No.1, 56-74, 2004.

[4] Dong, J. SVC usage comparison between heritage and baseline speakers of Mandarin Chinese in the Netherlands. MA thesis, Radboud University Nijmegen, 2014.

[5] Ding, S. Xiandai HanyuYyufa Jianghua [Lectures on Modern Chinese Grammar]. Beijing: Shangwu Yinshu Guan, 1979.

[6] Givón, T. Multiple routes to clause union: The diachrony of complex verb phrases. In Givón, T. and Masayoshi Shibatani (eds.), Syntactic Complexity: Diachrony, Acquisition, Neuro-cognition, Evolution. Amsterdam: John Benjamins, 81-118, 2009.

[7] Heydari, P., Bagheri, M. S. Error analysis: Sources of L2 learners' errors. Theory and Practice in Language Studies, Vol.2, No.8, 1583-1589, 2012.

[8] Jarvis, S., Pavlenko, A. Crosslinguistic Influence in Language and Cognition. London: Routledge, 2008.

[9] Jin, L. The development of aspect marking in L2 Chinese by English native speakers. Beijing: Foreign Language Teaching and Research Press, 2009.

[10] Li, C. N., Thompson, S. A. Mandarin Chinese: A Functional Reference Grammar. Berkeley, Los Angeles, London: University of California Press, 1981.

[11] Li, D., Cheng, M. A Practical Chinese Grammar for Foreigners (Revised Edition). Beijing: Beijing Language and Culture University, 2008.

[12] McEnery, T., Xiao, R. Corpus-based study of Chinese. In S. Chan (Ed.), The Routledge encyclopedia of the Chinese language, 438-452, 2016.

[13] Moattarian, A. Bidirectional crosslinguistic influence in language learning: Linguistic aspects and beyond. International Journal of Linguistics, Vol.5, No.4, 38-49, 2013. 
[14] Moro, F. Dynamics of Ambon Malay: Comparing Ambon and the Netherlands. Utrecht: LOT, 2016.

[15] Moro, F. Resultative constructions in heritage Ambon Malay in the Netherlands. Linguistics in the Netherlands, Vol.31, No.1, 78-92, 2014.

[16] Noonan, M. Complementation. In Shopen, Timothy (ed.).Language typology and syntactic description: Complex constructions. Volume 2, 42-140. Cambridge, England: Cambridge University Press, 1985.

[17] Odlin, T. Language Transfer. Cambridge: Cambridge University Press, 1989.

[18] Odlin, T. Crosslinguistic influence and conceptual Transfer: What are the concepts? Annual Review of Applied Linguistics, 25, 3-25, 2005.

[19] Selinker, L. Interlanguage. International Review of Applied Linguistics, 10, 209-231, 1972.

[20] Selinker, L. Rediscovering Interlanguage. London: Longman, 1992.

[21] Sun, X. Seiral Verb Constructions in Mordern Chinese and Its Acquisition. Nanjing Normal University, 2008.

[22] Tao, L. Serial verb construction in Mandarin Chinese: The interface of syntax and semantics. In Paper presented at the the 21st North American Conference on Chinese Linguistics (NACCL-21). Smithfield, Rhode Island: Bryant University, 2009.

[23] Wu, Y. Jiyu HSK Dongtai Zuowen Yuliaoku de Yingyu Guojia Butong Dengji Hanyu Xuexizhe Yupian Xianjie Pianwu Bijiao Yanjiu [A Comparative Study of Discourse Cohesion Errors of Chinese Learners of Different Levels in English-speaking Countries Based on HSK Dynamic Corpus]. ZheJiang University, 2014.

[24] Xing, X. Xiandai Hanyu Jianyushi [Pivotal Sentences in Modern Chinese]. Beijing: Communication University of China press, 2004.

[25] Yip, V. Interlanguage and Learnability: from Chinese to English. Amsterdam: John Benjamins, 1995.

[26] Yuan, B. Interpretation of binding and orientation of the Chinese reflexive Ziji by English and Japanese speakers. Second Language Research, Vol.14, No.4, 324-340, 1998.

[27] Zhou, W. A Corpus-based study on the acquisition of bi-constituent sentences. Language Teaching and Study, 3, 40-47, 2009.

[28] Zhou, W., Xiao, X. Zhongjieyu Pianwu Xinxi Yuliaoku [Interlanguage Error Information Corpus]. Nanjing Normal University, 2004. 